DURNAI, RIS'II
(Rekayasa Sistem dan Teknologi Informasi)
Vol.1 No.3 (2017) $239-249$ ISSN Media Elektronik : 2580-0760

\title{
Penilaian Strategic Alignment Model (SAM) dan Pemetaan Kerangka Kerja COBIT 4.1 pada PT. XYZ
}

\author{
Fransiska Prihatini Sihotang \\ Program Studi Sistem Informasi, STMIK GI MDP, fransiskaps@mdp.ac.id
}

\begin{abstract}
PT. XYZ is a manufacturing company that produces Type I Portland cement and Portland Composite Cement. PT. XYZ has used IS/IT to support its business processes, but does not know the alignment model between IS/IT that has been used against the company's business strategy. PT. XYZ also does not know the maturity level of the application of the IS/IT. This is because there has never been an assessment of the alignment of IS/IT strategy to business strategy and has never done the maturity level measurement from the application of IS/IT. Measurement of the maturity level of application of IS/IT can be done if it is known what processes should be measured. For that reason, mapping is required using a specific framework. Assessment of alignment of IS/IT strategy to business strategy at PT. XYZ uses Strategic Alignment Model (SAM), while to know the process to be measured maturity level used framework COBIT 4.1. The result of this research is known the alignment model of IS/IT strategy to business strategy and IS/IT process which can be measured maturity level in the next step.
\end{abstract}

Keywords: Strategic Alignment Model (SAM), IS/IT Alignment, Business Alignment, COBIT 4.1

\begin{abstract}
Abstrak
PT. XYZ merupakan perusahaan manufaktur Semen Portland Tipe I dan Semen Portland Komposit. PT. XYZ telah lama memanfaatkan SI/TI dalam mendukung proses bisnisnya, namun tidak mengetahui model keselarasan antara SI/TI yang telah digunakan tersebut terhadap strategi bisnis perusahaan. PT. XYZ juga tidak mengetahui tingkat kematangan dari penerapan SI/TI tersebut. Hal ini karena belum pernah dilakukan penilaian keselarasan strategi SI/TI terhadap strategi bisnis dan belum pernah melakukan pengukuran tingkat kematangan dari penerapan SI/TI. Pengukuran tingkat kematangan penerapan SI/TI dapat dilakukan jika sudah diketahui proses-proses apa saja yang harus diukur. Untuk itu, diperlukan pemetaan menggunakan kerangka kerja tertentu. Penilaian keselarasan strategi SI/TI terhadap strategi bisnis pada PT. XYZ menggunakan Strategic Alignment Model (SAM), sedangkan untuk mengetahui proses-proses yang akan diukur tingkat kematangannya digunakan kerangka kerja COBIT 4.1. Hasil dari penelitian ini adalah diketahui model keselarasan strategi SI/TI terhadap strategi bisnis dan proses-proses SI/TI yang dapat diukur tingkat kematangannya pada tahap selanjutnya.
\end{abstract}

Kata kunci: Strategic Alignment Model (SAM), Keselarasan SI/TI, Keselarasan Bisnis, COBIT 4.1

(c) 2017 Jurnal RESTI

\section{Pendahuluan}

Sistem informasi adalah seperangkat komponen yang saling terkait untuk mendukung pengambilan keputusan dan kontrol dalam sebuah organisasi [1]. Penerapan Sistem Informasi (SI) dan Teknologi Informasi (TI) untuk mendukung strategi bisnis sering dilakukan oleh perusahaan dengan harapan visi misi perusahaan dapat dicapai dengan mudah.

Agar pemanfaatan SI/ TI menjadi efektif dan efisien, diperlukan keselarasannya dengan strategi bisnis. Banyak pelaku bisnis yang sukses karena memanfaatkan teknologi dalam menciptakan keunggulan kompetitif perusahaannya, tetapi ada pula yang tidak diuntungkan oleh teknologi karena pihak manajerial yang tidak dapat memanfaatkannya dengan baik.

Organisasi yang kinerjanya terlihat baik adalah organisasi yang di dalamnya terdapat penyelarasan antara realisasi strategi bisnis dan realisasi strategi sistem informasi [2]. Kesuksesan bisnis dengan memanfaatkan teknologi, tidak terlepas dari tata kelola Teknologi Informasi (TI) yang baik. 
Tata kelola TI melibatkan pengelolaan operasional TI Strategic Alignment Model (SAM) merupakan suatu dan proyek TI untuk memastikan keselarasan antara kerangka kerja yang dapat digunakan untuk kegiatan tersebut dan kebutuhan organisasi menyelaraskan strategi TI dengan strategi bisnis. didefinisikan dalam rencana strategis perusahaan [3]. Secara konseptual penyelarasan tersebut dapat Tata kelola TI adalah tanggung jawab eksekutif dan mengarahkan peran strategis manajemen TI. dewan direksi, dan terdiri dari kepemimpinan, struktur Keselarasan strategi TI dengan strategi bisnis dapat organisasi, dan proses yang memastikan bahwa TI menciptakan keunggulan kompetitif organisasi melalui perusahaan mendukung dan memperluas strategi dan pemanfaatan TI yang berkelanjutan [5].

tujuan organisasi [4]. Pada tata kelola TI yang baik

terdapat kesesuaian antara strategi bisnis dengan 2.2 Kuadran SAM

infrastruktur organisasi, dan kesesuaian antara strategi TI dengan infrastruktur dan proses TI, untuk mencapai tujuan bisnis yang telah ditetapkan oleh organisasi [5].

SAM terdiri dari empat kuadran yang terdiri dari dua domain internal dan dua domain eksternal, yaitu kuadran strategi bisnis, kuadran strategi TI, kuadran PT. XYZ merupakan salah satu perusahaan manufaktur infrastruktur perusahaan dan berbagai prosesnya, serta penghasil semen di Indonesia yang lokasi pabrik dan kuadran infrastruktur TI dan berbagai prosesnya. SAM kantor pusatnya terpisah jarak yang cukup jauh. Untuk dapat digunakan sebagai dasar penilaian keselarasan itu, PT. XYZ telah mengimplementasikan SI/ TI yang strategi TI terhadap strategi bisnis.

terintegrasi sehingga dapat meningkatkan efisiensi dalam proses bisnis yang diharapkan akan meningkatkan daya saing di pasar bisnis.

Namun, sampai saat ini PT. XYZ belum pernah melakukan penilaian keselarasan strategi teknologi informasi terhadap strategi organisasi, padahal penilaian tersebut merupakan hal yang sangat penting untuk mengetahui apakah strategi TI yang selama ini diterapkan sudah mendukung strategi bisnis. PT. XYZ juga belum pernah melakukan pengukuran tingkat kematangan dari penerapan SI/ TI yang telah diterapkan. Pengukuran tingkat kematangan penerapan SI/ TI dapat dilakukan setelah diketahui proses-proses apa saja yang harus diukur. Untuk mengetahui prosesproses apa saja yang harus diukur, diperlukan pemetaan menggunakan kerangka kerja tertentu, dalam penelitian ini digunakan kerangka kerja COBIT 4.1.

Penelitian ini dilakukan dengan tujuan untuk mengetahui model keselarasan strategi TI terhadap strategi bisnis pada PT. XYZ dan melakukan pemetaan terhadap penerapan SI/TI perusahaan untuk mengetahui proses-proses apa saja yang pada tahap berikutnya akan diukur tingkat kematangannya.

\section{Tinjauan Pustaka/Penelitian Sebelumnya}

Bagian ini berisi tentang Strategic Alignment Model, COBIT 4.1, dan penelitian terdahulu yang dijadikan acuan dalam penelitian ini.

\subsection{Strategic Alignment Model (SAM)}

Keselarasan strategi antara bisnis dan TI berfokus pada upaya untuk memastikan adanya hubungan/ relasi antara rencana bisnis dengan TI; mencakup aktivitas pendefinisian, pemeliharaan, validasi nilai TI dan penyelarasan TI dengan operasional organisasi. Keselarasan strategis bisnis dan TI sebagai estafet awal dalam rangka menggali potensi manfaat TI bagi bisnis [4].

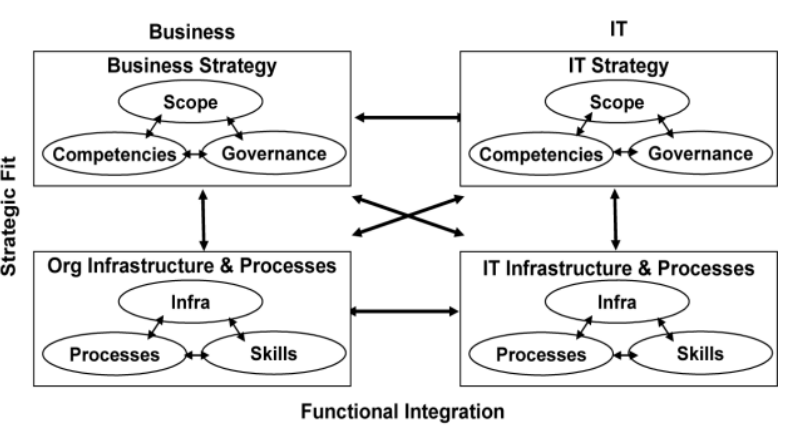

Gambar 1. Strategic Alignment Model (SAM)

Gambar 1 menjelaskan bahwa setiap kuadran atau domain pada SAM terdiri dari tiga komponen, sehingga jumlah kuadran atau domain SAM adalah dua belas komponen. Komponen tersebut saling berinteraksi dan dapat digunakan untuk menentukan tipe keselarasan strategi TI terhadap strategi bisnis pada perusahaan. Berikut adalah domain atau kuadran pada SAM [5].

1. Domain Strategi Bisnis.

a. Ruang lingkup organisasi (business scope), berfokus pada tipe/ jenis organisasi, peran organisasi dalam menentukan kompetensi nilai, dan isi organisasi.

b. Kompetensi khusus (distinctive competencies), meliputi keahlian khusus yang dimiliki organisasi, sejauh mana organisasi mampu melakukan yang terbaik dalam memberikan layanan kepada penggunanya. Domain ini mencakup strategi untuk meningkatkan kepuasan pengguna, layanan, fokus pada kualitas, serta penciptaan jalur distribusi layanan.

c. Tata kelola organisasi (business governance), mencakup hal yang berhubungan dengan tata kelola seperti membangun kerja sama dengan organisasi lain, dampak dari peraturan pemerintah, dan strategi outsourcing. 
2. Domain Strategi Teknologi Informasi.

secara vertikal yang biasa disebut sebagai kecocokan

a. Ruang lingkup teknologi (technology scope), strategis (strategic fit) yang merupakan hubungan berfokus pada teknologi dan aplikasi utama antara strategi bisnis dengan strategi TI yang yang dimiliki organisasi yang seharusnya merefleksikan suatu komponen eksternal. Strategic fit tersedia sesuai dengan kebutuhan TI. juga berkaitan dengan kemampuan fungsional TI untuk

b. Sistem kompetensi (system competencies), membentuk atau mendukung strategi bisnis. terdiri dari organisasi, aksebilitas, kehandalan, Keterkaitan kedua adalah secara horisontal yang biasa karakteristik, dan kekuatan terkait TI yang disebut sebagai integrasi fungsional (functional dimiliki organisasi.

integration). Integrasi fungsional menunjukkan

c. Tata kelola TI (IT governance), meliputi seberapa jauh integrasi antara strategi bisnis sudah keputusan untuk membeli atau membuat sesuai dengan strategi sistem teknologi informasi. aplikasi, menentukan prioritas aplikasi dan Integrasi fungsional dapat dipisahkan menjadi dua sistem informasi, serta kemungkinan untuk macam integrasi sebagai berikut [5].

melakukan kerja sama atau outsourcing.

3. Domain Infrastruktur Perusahaan dan Berbagai Proses.

a. Infrastruktur Administratif (Administrative Infrastucture), meliputi struktur organisasi, tanggung jawab, dan peran dalam organisasi.

b. Proses (Process), meliputi aktivitas dalam organisasi yang dapat menentukan sejauh mana tingkat pekerjaan dapat diintegrasikan dengan TI. Perbaikan proses di dalam organisasi dapat bersumber dari TI atau dari proses baru yang dirancang untuk dapat diintegrasikan dengan TI yang semakin hari semakin berkembang luas.

c. Keahlian (Skills), berfokus pada sumber daya manusia dalam organisasi, khususnya yang berkaitan dengan keahlian yang dimiliki tenaga kerja, pelatihan yang tersedia, pengalaman tenaga kerja, dan penciptaan budaya organisasi.

4. Infrastruktur Teknologi Informasi.

a. Infrastruktur Teknologi Informasi (IT Infrastructure) meliputi perangkat keras, perangkat lunak, data, aplikasi, dan platform komunikasi yang digunakan organisasi untuk mencapai strategi bisnis dan strategi TI.

b. Proses (Process), berfokus pada pengembangan praktek TI secara khusus dan bagaimana proses tersebut dapat selalu ditingkatkan. Komponen ini meliputi pengembangan aplikasi sistem informasi, manajemen sistem, dan pemeliharaan terhadap sistem yang ada.

c. Keahlian (Skills), mencakup pengalaman, kompetensi, dan nilai yang dimiliki oleh pekerja di bidang TI.

\subsection{Keterkaitan dalam SAM}

Dalam SAM terdapat inter-relationship yang merefleksikan keterkaitan antara empat kuadran atau domain. Jika keempat domain digunakan secara bersama-sama maka menghasilkan suatu nilai tambah yang akan saling melengkapi. Tujuan organisasi dapat dicapai melalui berbagai keterkaitan (linkage) seperti terlihat pada Gambar 1. Keterkaitan pertama adalah
1. Integrasi strategis (strategic integration): menggandengkan antara strategi bisnis dengan strategi sistem teknologi informasi dengan penekanan pada domain eksternal.

2. Integrasi operasional (operational integration): berhubungan dengan domain internal, yaitu antara infrastruktur dan proses-proses organisasional dengan infrastruktur dan proses-proses sistem teknologi informasi.

\subsection{Perspektif SAM}

Dalam SAM terdapat empat perspektif sebagai berikut [5].

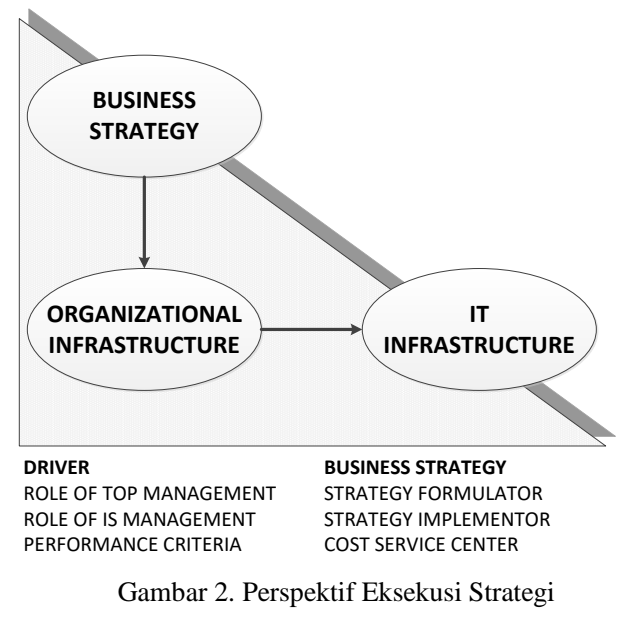

1. Eksekusi Strategi (Strategy Execution) seperti terlihat pada Gambar 2, strategi bisnis berperan sebagai driver yang berarti bahwa organisasi sudah memiliki strategi yang kuat. Infrastruktur organisasi adalah domain pivot atau domain yang lemah, sedangkan infrastruktur TI adalah domain yang terpengaruh.

2. Transformasi Teknologi (Technology Transformation) seperti terlihat pada Gambar 3, menempatkan strategi bisnis sebagai driver atau penggerak utama. Strategi bisnis berperan sebagai domain anchor, strategi TI sebagai domain pivot, dan infrastruktur TI sebagai domain terpengaruh. 


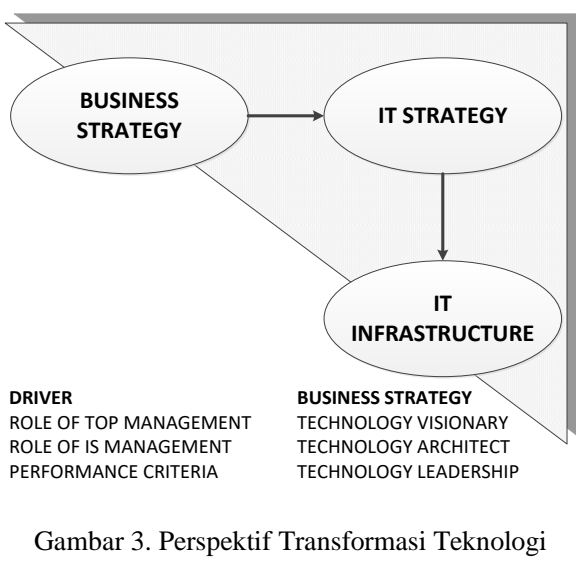

Gambar 3. Perspektif Transformasi Teknologi

3. Potensi Kompetitif (Competitive Potential) sepert terlihat pada Gambar 4, yang berperan sebagai investasi TI, jaminan pelayanan, dan penetapan ukuran driver adalah strategi TI atau merupakan domain terhadap hal-hal yang dianggap belum tepat. Supaya TI anchor, strategi bisnis adalah domain pivot, dan dapat memenuhi kebutuhan organisasi secara infrastruktur organisasi adalah domain terpengaruh. maksimal, maka manajemen harus melakukan

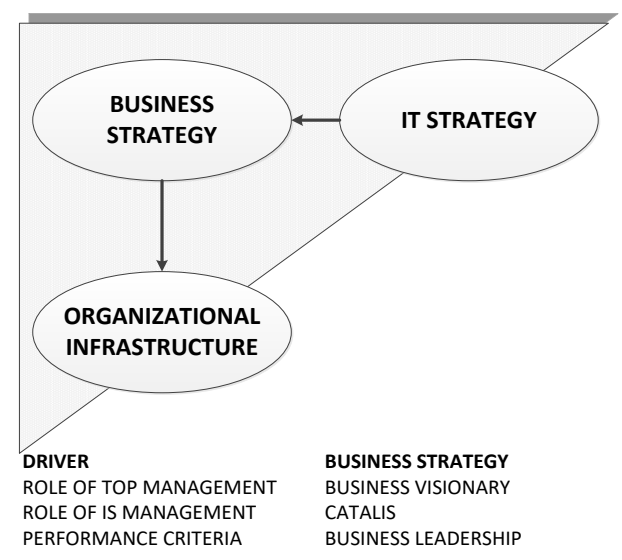

Gambar 4. Perspektif Potensi Kompetitif

4. Tingkat Pelayanan (Service Level) seperti terlihat pada Gambar 5, menempatkan strategi TI sebagai Seperti yang terlihat pada Gambar 6, COBIT 4.1 driver atau domain anchor, domain pivot adalah memiliki empat domain yang dipetakan dari proses TI infrastruktur TI, sedangkan domain terpengaruh tradisional sebagai berikut [4]. adalah indrastruktur organisasi.

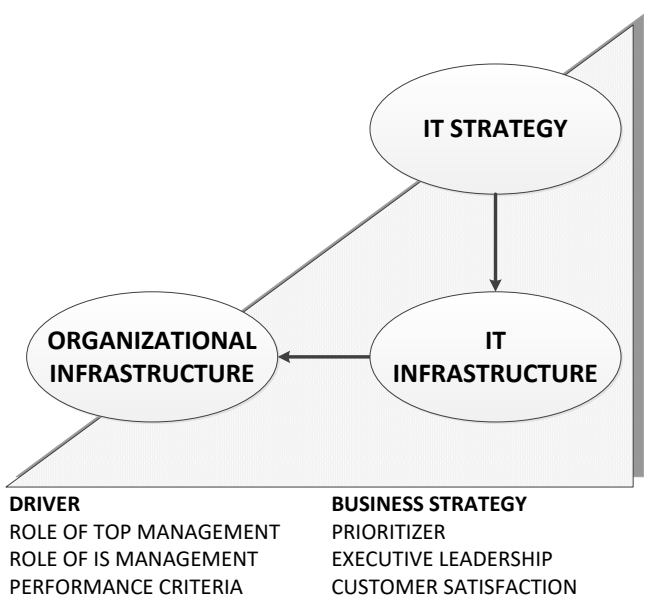

Gambar 5. Perspektif Tingkat Pelayanan

\subsection{COBIT 4.1}

Control Objective of Information Technology (COBIT) 4.1 merupakan salah satu framework untuk menciptakan tata kelola TI dalam suatu organisasi yang dapat mempertemukan kebutuhan manajemen dengan cara menjembatani celah antara risiko bisnis, kebutuhan kontrol, dan masalah-masalah teknis TI. COBIT memberikan panduan dalam pengendalian fungsi-fungsi TI untuk dapat efektif dan efisien dalam mendukung organisasi dengan cara memberikan nilai tambah yang maksimal dari setiap investasi yang dilakukan dengan meminimalkan risiko aktivitas yang dapat terjadi.

COBIT berfokus pada pengendalian, bukan pada tahap pengendalian sistem internal.

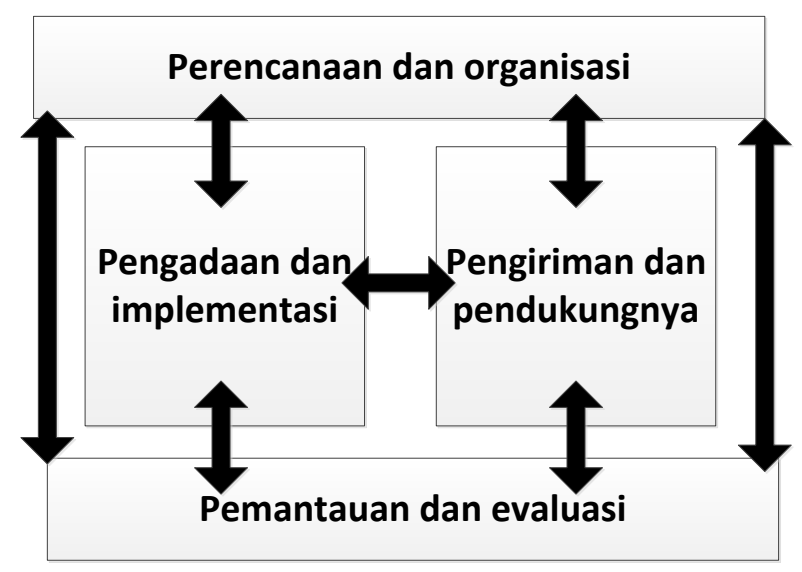

Gambar 6. Hubungan Antar Domain pada COBIT 4.1

1. Plan and organise, memberikan arahan dalam memberikan solusi (AI) dan memberikan layanan (DS).

2. Acquire and implement, memberikan solusi dan mengubahnya menjadi suatu layanan.

3. Deliver and support, menerima solusi dan menjadikannya tersedia bagi pengguna akhir.

4. Monitor and evaluate, memonitor seluruh proses untuk memastikan arahan yang telah disediakan telah diikuti dengan benar.

\subsection{Domain Plan and Organize pada COBIT 4.1}

Domain ini mencakup penentuan strategi, taktik, dan identifikasi kontribusi TI dalam pencapaian tujuan perusahaan. Domain ini memiliki sepuluh proses yang 
harus diidentifikasi pada suatu organisasi, sebagai 2.7 Domain Acquire and Implementation pada COBIT berikut [4].

\section{1}

Untuk merealisasikan strategi TI, perlu dilakukan Menggabungkan manajemen TI dengan manajemen pengindentifikasian, pengembangan, dan perolehan organisasi untuk mendapatkan hal-hal yang solusi TI, sesuai dengan yang akan diimplementasikan diperlukan dalam menghasilkan suatu layanan, serta dan diintegrasikan ke dalam proses bisnis. Domain ini mengembangkan strategi dalam memberikan memiliki tujuh proses yang harus diidentifikasi pada layanan secara transparan dan efektif.

2. PO2: Define the information architecture Pembentukan model data organisasi yang
menggabungkan skema klasifikasi data untuk menjamin integritas dan konsistensi data.

3. PO3: Determine technological direction Mendefinisikan dan menerapkan rencana infrastruktur teknologi, arsitektur, dan standar yang dapat digunakan untuk memanfaatkan peluang dalam teknologi.

4. PO4: Define the IT processes, organizatios and relationship

Membangun struktur TI yang terorganisir secara transparan, fleksibel, dan responsif, serta mendefinisikan proses-proses TI. Peran dan tanggung jawab yang ada di organisasi diintegrasikan ke dalam proses pengambilan keputusan.

5. PO5: Manage the IT investment

Menentukan langkah yang tepat dalam melakukan investasi TI secara efektif dan efisien dengan cara memastikan bahwa anggaran TI selaras dengan strategi TI dan keputusan dalam investasi.

6. PO6: Communicate management aims and direction

Membuat suatu kebijakan, prosedur, panduan, dan dokumentasi lainnya secara akurat, serta dapat dimengerti dan disetujui oleh manajemen. Dokumen ini tertuang di dalam sebuah kerangka kerja pengendalian TI.

7. PO7: Manage IT human resources Meliputi perekrutan dan pelatihan personil, memberikan motivasi melalui jalur karir yang jelas, menentukan peran yang sesuai dengan keahlian, melaksanakan proses evaluasi yang telah ditetapkan, membuat gambaran terhadap suatu posisi/jabatan, dan memastikan adanya kesadaran saling ketergantungan antara yang satu dengan yang lainnya.

8. PO8: Manage quality

Memastikan kualitas dan layanan yang dihasilkan TI sudah berkesinambungan serta proses peningkatannya dapat diukur.

9. PO9: Assess and manage IT risk

Menganalisis dan mengkomunikasikan risiko terkait TI yang dapat terjadi dan dampaknya pada proses dan tujuan organisasi.

10. PO10: Manage projects

Memastikan hasil yang dicapai dalam suatu proyek tepat waktu, anggaran, dan kualitas, serta sudah sesuai dengan kesepakatan sebelumnya. suatu organisasi, sebagai berikut [4].

1. AI1: Identify automated solutions

Menerjemahkan fungsi organisasi dan hal-hal yang diperlukan dalam pengendaliannya ke dalam suatu desain solusi yang otomatis secara efektif dan efisien.

2. AI2: Acquire and maintain application software kebutuhan organisasi, serta membangunnya dalam waktu yang tepat dengan anggaran yang sesuai.

3. AI3: Acquire and maintain technology infrastructure

Menyediakan platform yang tepat untuk aplikasi organisasi yang selaras dengan arsitektur TI serta sesuai dengan standar teknologi yang telah ditentukan.

4. AI4: Enable operations and use

Memastikan kepuasan pengguna berdasarkan layanan yang ditawarkan, tingkatan pelayanan, dan keberhasilan pengintegrasian solusi aplikasi dan teknologi ke dalam suatu proses organisasi.

5. AI5: Procure IT resources

Meningkatkan efisiensi pengguna TI dan kontribusinya terhadap profitabilitas organisasi.

Menjelaskan kebutuhan organisasi dengan strategi bisnis melalui pengurangan duplikasi pekerjaan dan kerusakan pada penyediaan solusi dan layanan.

7. AI7: Install and accredit solutions and changes Mengimplementasikan suatu sistem baru atau melakukan perubahan pada sistem yang sudah ada dengan tidak menimbulkan masalah yang berarti setelah proses instalasi.

Domain ini berhubungan dengan segala sesuatu yang terkait dalam suatu layanan, termasuk di dalamnya mencakup pemberian layanan, pengelolaan keamanan dan kelancarannya, layanan pendukung bagi pengguna, seta pengelolaan fasilitas data dan operasional. Domain ini memiliki tiga belas proses yang harus diidentifikasi pada suatu organisasi, sebagai berikut [4].

1. DS1: Define and manage service levels Mengidentifikasi kebutuhan layanan, menyetujui tingkat layanan yang ingin dicapai, serta melakukan pemantauan terhadap pencapaiannya.

2. DS2: Manage third party service

Membangun hubungan dan tanggung jawab bilateral dengan pihak ketiga penyedia layanan Menyelaraskan aplikasi yang tersedia terhadap

6. AI6: Manage Changes

\subsection{Domain Deliver and Support pada COBIT 4.1}


yang sudah dikualifikasi serta memantau hasil empat proses yang harus diidentifikasi pada suatu layanan untuk memastikan bahwa semua yang telah organisasi, sebagai berikut [4]. dikerjakan sesuai dengan perjanjian.

3. DS3: Manage performance and capacity Mengoptimalkan kinerja infrastruktur, sumber daya, dan kemampuan untuk memenuhi kebutuhan organisasi.

4. DS4: Ensure continuous service

Memastikan dampak yang diakibatkan gangguan TI seminimal mungkin.

5. DS5: Ensure systems security

Mempertahankan integritas pengolahan informasi dan infrastruktur, serta meminimalisasi dampak dari rentannya keamanan TI.

6. DS6: Identify and allocate cost

Memastikan transparansi dan pemahaman tentang anggaran TI, serta meningkatkan efisiensi penggunaan anggaran melalui pemanfaatan layanan TI yang tepat.

7. DS7: Educate and train users

Pemahaman yang jelas tentang perlunya pelatihan untuk pengguna TI, bagaimana strategi pelaksanaan pelatihan yang efektif, serta pengukuran terhadap hasil penilaian.

8. DS8: Manage service desk and incident

Memungkinkan sistem TI digunakan secara efektif dengan pemecahan masalah dan analsis terhadap keraguan, pertanyaan, dan insiden dari pengguna.

9. DS9: Manage the configuration

Membangun dan mempertahankan repository dari atribut dan baselines konfigurasi aset yang akurat dan lengkap, sera membandingkannya dengan konfigurasi aset yang aktual.

10. DS10: Manage problems

Merekam, melacak, dan menyelesaikan masalah- Penelitian dengan framework lainnya juga pernah masalah operasional, serta menyelidiki akar dilakukan, yaitu pada Universitas XYZ menyimpulkan penyebab semua masalah guna mendapatkan solusi bahwa tingkat kematangan keselarasannya berada pada yang tepat.

11. DS11: Manage data

Mempertahankan kelengkapan, keakurasian, berada pada level 2 (Committed Process) [11].

ketersediaan dan perlindungan terhadap data.

12. DS12: Manage the physical environment

Menyediakan dan memelihara lingkungan fisik yang sesuai untuk melindungi aset TI dari penyimpangan akses, kerusakan, dan pencurian.

13. DS13: Manage operation.

Menjaga integritas data dan memastikan infrastruktur TI dapat mencegah serta melindungi data dari kerusakan dan kegagalan.

\subsection{Domain Monitor and Evaluate pada COBIT 4.1}

Semua proses TI perlu diperiksa secara periodik dan berkelanjutan untuk menjaga kualitas dan pemenuhan terhadap pengendaliannya. Domain ini menunjukkan hasil kinerja manajemen, pengawasan terhadap pengendalian internal, dan pemenuhan terhadap pengaturan dan pengelolaan. Domain ini memiliki
1. ME1: Monitor and evaluate IT performance Memantau dan melapokan proses pengukuran dan identifikasi serta melaksanakan tindakan peningkatan dan perbaikan.

2. ME2: Monitor and evaluate internal control Memantau proses pengendalian internal terhadap aktifitas yang berhubungan dengan TI, serta mengidentifikasi langkah-langkah perbaikannya.

3. ME3: Ensure compliance with external requirements

Memastikan kontrak yang disusun sesuai dengan hukum, peraturan, dan persyaratan yang disepakati bersama.

4. ME4: Provide IT governance

Mengintegrasikan tata kelola TI dengan tujuan tata kelola organisasi, serta menyesuaikan dengan hukum, peraturan, dan kontrak.

Sebelumnya pernah dilakukan penelitian sejenis menggunakan framework COBIT 4.1 dan SAM, di antaranya pengukuran kematangan keselarasan strategi TI terhadap strategi bisnis pada Bank Rakyat Indonesia yang menyimpulkan bahwa keselarasan strategi TI dan strategi bisnis BRI berada dalam level 3 (Defined), dan dinilai telah komprehensif, koheren, dan berimbang [6]. Penelitian pada Sistem Informasi Absensi PT. Bank Central Asia Tbk dan Sekretariat Negara berada dalam level 2 (Repeatable and Intuitive) [7], [8]. Penelitian pada Sistem Informasi Akademik UIN Syarif Hidayatullah Jakarta berada pada level 1 (Repeatable and Intuitive) dan level 2 (Initial/ Ad-Hoc) [9]. level 1 (Initial/ Ad-Hoc) [10]. Serta penelitian pada AMIK XYZ menyimpulkan bahwa instansi tersebut

\section{Metodologi Penelitian}

Gambar 7 memperlihatkan alur penelitian yang dilakukan dalam penelitian ini.

\subsection{Pengumpulan Data}

Selain melakukan studi literatur, pengumpulan data juga dilakukan dengan melakukan wawancara, analisis dokumen, dan observasi. Data primer diperoleh dengan melakukan wawancara kepada narasumber yang merupakan pimpinan biro ICT dan karyawan PT. XYZ.

Dokumen organisasi yang dianalisis dalam penelitian ini berupa dokumen rencana strategis PT. XYZ dan beberapa dokumen lainnya yang terkait dengan penelitian ini. Sedangkan observasi yang dilakukan yaitu pengamatan terhadap aplikasi yang digunakan dan kegiatan bisnis yang dilakukan perusahaan. 


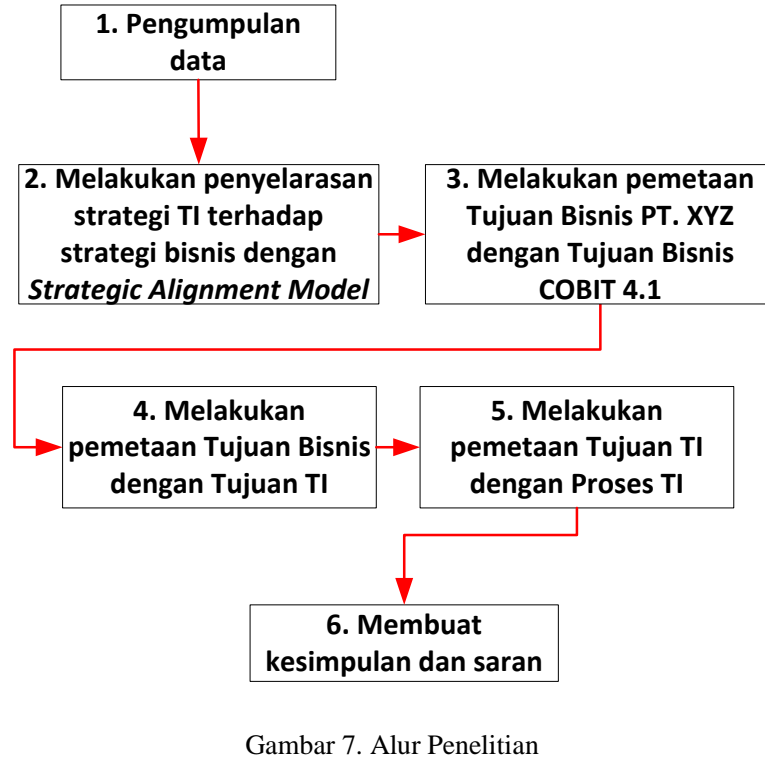

3.2 Melakukan Penyelarasan Strategi TI terhadap Strategi Bisnis dengan Strategic Alignment Model

Data yang sudah dikumpulkan dari wawancara, observasi, dan analisis dokumen organisasi digunakan sebagai bahan untuk dianalisis dengan Strategic Alignment Model.

3.3 Melakukan Pemetaan Tujuan Bisnis PT. XYZ dengan Tujuan Bisnis COBIT 4.1

Tahap ini merupakan tahap pertama dalam kerangka kerja COBIT 4.1. Data yang digunakan dalam penelitian ini adalah dokumen PT. XYZ yang berisi tentang visi misi perusahaan, visi misi organisasi, dan dokumen tentang strategi dan keunggulan kompetitif yang dimiliki oleh perusahaan.

3.4 Melakukan pemetaan Tujuan Bisnis dengan Tujuan TI

Setelah didapat hasil pemetaan pada tahap sebelumnya, maka dapat dilakukan pemetaan tujuan bisnis tersebut dengan tujuan TI pada COBIT 4.1.

\subsection{Melakukan pemetaan Tujuan TI dengan Proses TI}

Setelah didapat hasil pemetaan tujuan bisnis dengan tujuan TI yang telah didapat dari tahap sebelumnya, langkah berikutnya adalah memetakan tujuan TI tersebut dengan proses TI. Proses TI tersebut dianalisis dengan teknik kuisioner yang diisi oleh pihak terkait pada PT. XYZ. Selain teknik kuisioner, dilakukan juga observasi dan wawancara.

\subsection{Membuat Kesimpulan dan Saran}

Perumusan kesimpulan dan saran merupakan tahapan terakhir dari penelitian ini. Kesimpulan dibuat berdasarkan hasil penelitian yang sudah dilakukan.
Saran diberikan kepada peneliti selanjutnya yang memiliki keinginan untuk meneruskan penelitian ini atau ingin melakukan penelitian sejenis di tempat yang berbeda.

\section{Hasil dan Pembahasan}

Bagian ini berisi tentang hasil penelitian, yaitu berupa model keselarasan dan proses-proses TI.

\subsection{Analisis Domain Strategi Bisnis dengan SAM}

Analisis SAM digunakan untuk memberikan gambaran mengenai keselarasan antara strategi TI terhadap strategi bisnis dan model perspektif dari keselarasan tersebut pada perusahaan. Analisis domain strategi bisnis menjelaskan tentang analisis yang dilakukan terhadap domain strategi bisnis yang terdapat pada PT. XYZ. Strategi bisnis terdiri dari tiga komponen yaitu ruang lingkup bisnis, kompetensi yang membedakan, dan tata kelola bisnis. Hasil analisis diperlihatkan pada Tabel 1, 2, dan 3 .

Tabel 1. Ruang Lingkup Bisnis

\begin{tabular}{llr}
\hline $\begin{array}{l}\text { Ruang Lingkup } \\
\text { Bisnis }\end{array}$ & Hasil Analisis & \\
\hline Line of Business & $\begin{array}{l}\text { Bergerak dalam bidang } \\
\text { penggilingan bahan } \\
\text { pembuatan dan pengemasan semen, serta } \\
\text { distribusi kepada konsumen. }\end{array}$ \\
& $\begin{array}{l}\text { Provinsi Sumatera Selatan: 48\% } \\
\text { Lampung: 28\% }\end{array}$ \\
Market/Pasar & Jambi: 2\% \\
Produk & dan & \\
Layanan & $\begin{array}{l}\text { Pemen Portland Tipe-I (OPC) dan Semen } \\
\text { Pak, big bag, dan curah. }\end{array}$ \\
Pelanggan & Perusahaan lain, masyarakat. \\
(Customer) & & \\
\hline
\end{tabular}

Tabel 2. Kompetensi yang Membedakan

\begin{tabular}{ll}
\hline Kompetensi yang & Hasil Analisis \\
Membedakan & Menguasai pasar semen untuk propinsi \\
& Sumatera Selatan dan Lampung \\
& Branding yang kuat \\
& Kinerja Perseroan yang terus meningkat \\
& Keberlangsungan pasokan semen dan \\
jaringan distribusi yang kuat, didukung \\
Competencies & oleh: lokasi operasional Perseroan yang \\
& strategis karena terletak pada pasar \\
& utama, manajemen yang berpengalaman \\
& serta dukungan yang kuat dari \\
& Pemerintah Indonesia selaku Pemegang \\
& Saham. \\
& Ordinary Portland Cement (OPC) Tipe I \\
& (Indonesian Standard : SNI 15-2049- \\
& 2004, American Standard: ASTM C \\
& $150-04 a$, European Standard: EN 197- \\
& $1: 2000)$ \\
& Portland Composite Cement (PCC) \\
& (Indonesian Standard: SNI 15 7064- \\
& 2004, European Standard: EN 197- \\
& $1: 2000$ (42.5 N \& 42.5 R)) \\
& Selain sertifikat tersebut, perusahaan \\
& juga beberapa kali mendapatkan \\
& penghargaan bergengsi. \\
Brands/ merek &
\end{tabular}




\begin{tabular}{lll}
\hline $\begin{array}{l}\text { Kompetensi yang } \\
\text { Membedakan }\end{array}$ & Hasil Analisis \\
\hline Sales & $\&$ & PT. XYZ sudah sangat dikenal oleh \\
$\begin{array}{l}\text { Distribution } \\
\text { Channels }\end{array}$ & & masyarakat luas.
\end{tabular}

Tabel 3. Tata Kelola Bisnis

\begin{tabular}{ll}
\hline & Visi dan Misi perusahaan, buku \\
& Pedoman Tata Kelola Perusahaan dan \\
& Perilaku (Code of Conduct) diberikan \\
& kepada seluruh karyawan dan \\
& stakeholders, pembentukan tim audit \\
Hasil Analisis Tata & internal untuk memantau pelaksanaan \\
Kelola Bisnis & tata kelola perusahaan yang \\
& diimplementasikan di seluruh jajaran \\
& perusahaan, Assessment Good \\
& Corporate Governance (GCG) oleh \\
& Auditor Eksternal, rapat dewan \\
& komisaris dan direksi setiap bulan. \\
&
\end{tabular}

4.2 Analisis Domain Infrastruktur Perusahaan dan Berbagai Proses dengan SAM

Tabel 4 merupakan hasil analisis terhadap domain infrastruktur perusahaan dan berbagai prosesnya.

Tabel 4. Infrastruktur Perusahaan dan Berbagai Proses

\begin{tabular}{|c|c|}
\hline $\begin{array}{l}\text { Infrastruktur } \\
\text { Perusahaan dan } \\
\text { Berbagai Proses }\end{array}$ & Hasil Analisis \\
\hline $\begin{array}{l}\text { Infrastruktur } \\
\text { Administratif }\end{array}$ & $\begin{array}{l}\text { Posisi tertinggi PT. XYZ adalah } \\
\text { direktur utama yang membawahi } \\
\text { direktur teknik, direktur produksi, } \\
\text { direktur komersial, dan direktur } \\
\text { umum/SDM. } \\
\text { Yang berada di posisi ketiga adalah } \\
\text { sekretaris, departemen SPI, } \\
\text { departement LITBANG, departemen } \\
\text { operasi, departemen keuangan, } \\
\text { departemen pemasaran, departemen } \\
\text { logistik, dan departemen SDM dan } \\
\text { umum. } \\
\text { Masing-masing departemen tersebut } \\
\text { dibagi lagi menjadi staf bidang legal } \\
\text { \& sekretariat, pemeriksaan, } \\
\text { pemeriksaan operasional, tim } \\
\text { persiapan proyek, penelitian BBPP, } \\
\text { rancang bangun, SIM, produksi, } \\
\text { PBM, pemeliharaan, pabrik, } \\
\text { akuntansi, perbendaharaan, anggaran, } \\
\text { pemasaran, penjualan, distribusi, } \\
\text { pengadaan, umum, SDM dan afiliasi, } \\
\text { dan KBL. }\end{array}$ \\
\hline Proses (Process) & $\begin{array}{l}\text { Proses bisnis utama bergerak dalam } \\
\text { bidang usaha penggilingan bahan } \\
\text { dasar semen, pembuatan dan } \\
\text { pengemasan semen, serta distribusi } \\
\text { kepada konsumen. }\end{array}$ \\
\hline Keahlian (Skill) & $\begin{array}{l}\text { Kompetensi yang dimiliki oleh } \\
\text { karyawan PT. XYZ sesuai dengan } \\
\text { keahlian dan bidang kerjanya. } \\
\text { Perusahaan juga mengadakan } \\
\text { berbagai program pelatihan terkait } \\
\text { dengan keahlian masing-masing } \\
\text { karyawan sesuai dengan kebutuhan. }\end{array}$ \\
\hline
\end{tabular}

\subsection{Analisis Domain Strategi TI dengan SAM}

Tabel 5 merupakan hasil analisis terhadap domain strategi TI yang terdapat pada PT. XYZ.

Tabel 5. Domain Strategi TI

\begin{tabular}{ll}
\hline Domain Strategi TI & Hasil Analisis \\
\hline $\begin{array}{l}\text { Ruang Lingkup } \\
\text { Teknologi } \\
\text { (Technology Scope) }\end{array}$ & $\begin{array}{l}\text { Dikembangkan sendiri: CIS, Program } \\
\text { Timbangan Truk, Entrian Produksi, } \\
\text { dan Intranet. } \\
\text { Beli: E-Procurement, Trial Program } \\
\text { Payrol (dalam tahap pembuatan) }\end{array}$ \\
$\begin{array}{l}\text { Tata Kelola TI (IT } \\
\text { Governance) XYZ telah memiliki divisi/unit } \\
\text { bisnis khusus yang mengatur kegiatan }\end{array}$ \\
$\begin{array}{l}\text { TI, yaitu Biro ICT. } \\
\text { Staff Biro ICT menguasai sistem } \\
\text { (Competencies }\end{array}$ \\
$\begin{array}{l}\text { System) } \\
\text { beberasi, perangkat lunak, dan } \\
\text { windows, windows server, PHP, } \\
\text { Oracle, SQL Server, MySQL, Java. }\end{array}$ \\
\hline
\end{tabular}

4.4 Analisis Domain Infrastruktur TI dan Berbagai Proses dengan SAM

Tabel 6 merupakan hasil analisis yang dilakukan terhadap domain infrastruktur TI dab berbagai prosesnya yang terdapat pada PT. XYZ.

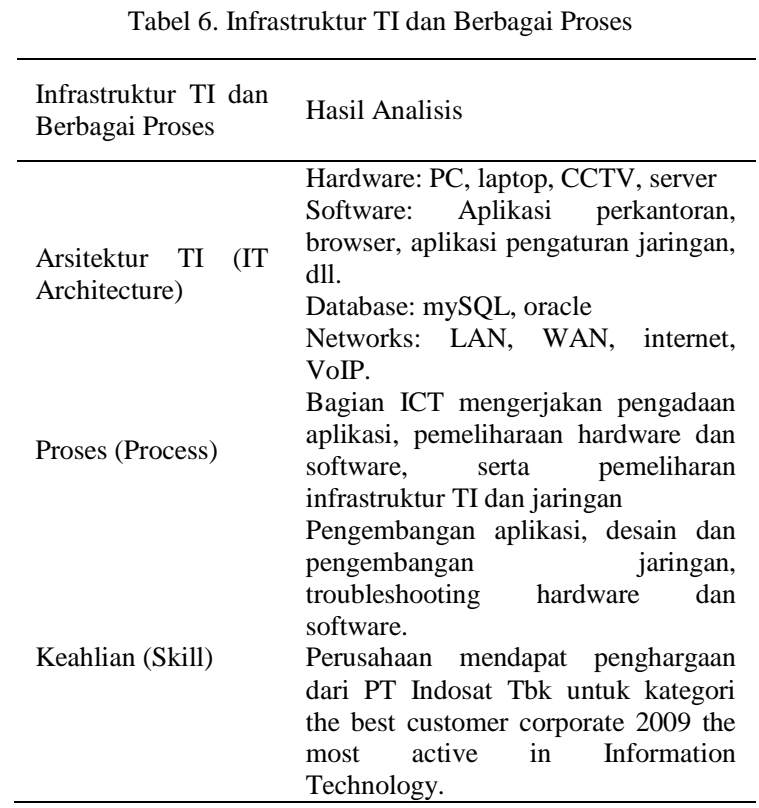

\subsection{Keselarasan Strategi Bisnis dan Strategi TI}

Berdasarkan analisis yang telah dilakukan, diketahui bahwa strategi bisnis dan strategi TI pada PT. XYZ telah selaras. Dalam lingkup bisnis, strategi bisnis yang ditetapkan menentukan penetapan keputusan dalam infrastruktur organisasi. Pada infrastruktur administratif terdapat tanggung jawab dan wewenang, serta penentuan keahlian yang dibutuhkan oleh organisasi. Sedangkan dalam lingkup TI dinyatakan selaras karena strategi TI mempengaruhi penentuan infrastuktur TI. 
Antara lingkup bisnis dan lingkup TI juga diperlukan integrasi fungsional sehingga TI dapat memahami kebutuhan bisnis dan bisnis mendapatkan manfaat dari investasi dan proses TI. Berdasarkan hasil analisis, diketahui bahwa integrasi fungsional pada PT. XYZ telah diterapkan. Hal ini diperkuat pula dengan isi dari visi dan misi Biro ICT PT. XYZ, sehingga dapat disimpulkan bahwa terdapat integrasi fungsional antara lingkup bisnis dengan lingkup TI dan sebaliknya.

Domain terkuat pada PT. XYZ adalah strategi bisnis yang memengaruhi infrastruktur organisasi dan strategi TI, kemudian strategi TI tersebut mempengaruhi infrastruktur TI, seperti yang ditampilkan pada Gambar 8. Merujuk pada empat perspektif yang dominan pada SAM, PT. XYZ berada pada perspektif transformasi teknologi (technology transformation). Strategi bisnis berperan sebagai domain anchor, strategi TI sebagai domain pivot, dan infrastruktur TI sebagai domain terpengaruh. Artinya strategi bisnis berperan sebagai penentu dari strategi TI, dan infrastruktur TI akan terpengaruh secara langsung apabila terjadi perubahan strategi TI.

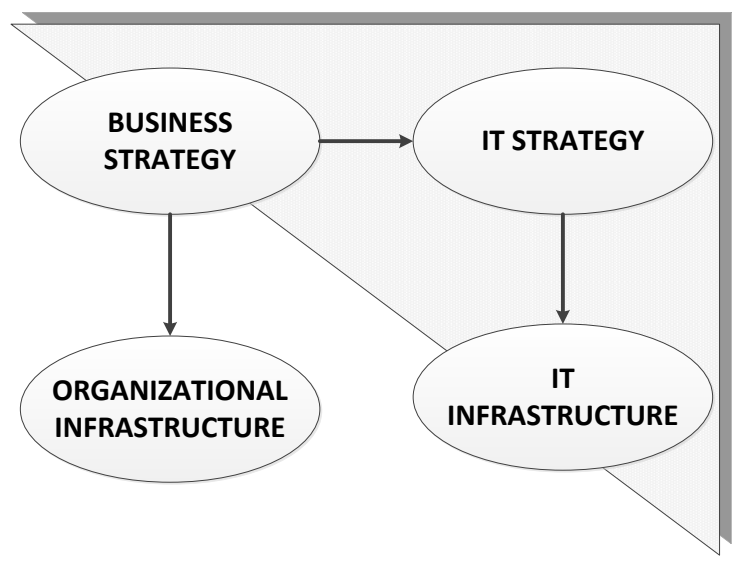

Gambar 8. Keselarasan Strategi Bisnis dan Strategi TI pada PT. XYZ

\subsection{Pemetaan Tujuan Bisnis PT. XYZ dengan Tujuan Bisnis Xobit 4.1}

Tahap ini merupakan tahap pertama yang dilakukan dalam kerangka kerja COBIT 4.1. Adapun data yang digunakan dalam tahap ini adalah dokumen perusahaan yang berisi tentang visi misi perusahaan, visi misi Biro ICT, dan dokumen tentang strategi serta keunggulan kompetitif yang dimiliki oleh PT. XYZ.

Hasil analisis pemetaan tujuan bisnis PT. XYZ dengan Tujuan TI kerangka kerja COBIT 4.1, dapat dilihat pada Tabel 7. Berdasarkan analisis yang dilakukan, diketahui bahwa tujuan bisnis pada PT. XYZ yang sesuai dengan kerangka kerja COBIT 4.1 adalah tujuan bisnis dengan nomor $1,3,4,5,6,9,14$, dan 15 .
Tabel 7. Pemetaan Tujuan Bisnis Perusahan dengan Tujuan TI pada PT. XYZ

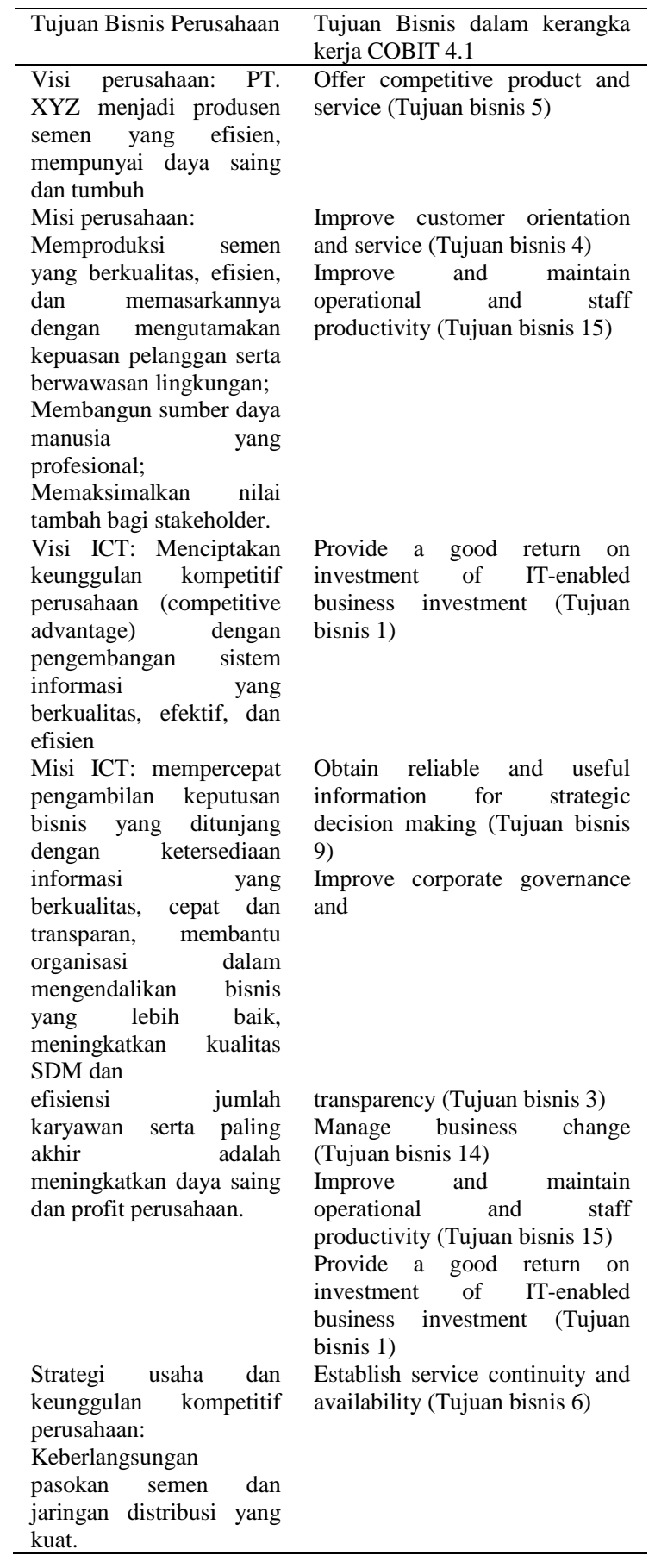

\subsection{Pemetaan Tujuan Bisnis dengan Tujuan TI}

Hasil analisis pada Tabel 7 dipetakan lagi dengan tujuan TI yang ada pada COBIT 4.1, sehingga didapat hasil seperti yang dapat dilihat pada Tabel 8. 
Tabel 8. Rangkuman Pemetaan Tujuan Bisnis dengan Tujuan TI pada PT. XYZ

\begin{tabular}{|c|c|c|c|c|c|}
\hline Tujuan Bisnis & \multicolumn{5}{|c|}{ Tujuan TI } \\
\hline 1 & 24 & & & & \\
\hline 3 & 2 & 18 & & & \\
\hline 4 & 3 & 23 & & & \\
\hline 5 & 5 & 24 & & & \\
\hline 6 & 10 & 16 & 22 & 23 & \\
\hline 9 & 2 & 4 & 12 & 20 & 26 \\
\hline 14 & 1 & 5 & 6 & 11 & 28 \\
\hline 15 & 7 & 8 & 11 & 13 & \\
\hline
\end{tabular}

\subsection{Pemetaan Tujuan TI dengan Proses TI}

Setelah didapat hasil pemetaan tujuan bisnis dengan tujuan TI, langkah berikutnya adalah memetakan tujuan TI tersebut dengan proses TI seperti yang terangkum pada Tabel 9. Proses TI tersebut dianalisis dengan teknik kuisioner yang diisi oleh pihak terkait di PT.XYZ. Selain teknik kuisioner, dilakukan juga observasi dan wawancara baik secara langsung maupun tidak langsung. Untuk memudahkan penilaian kematangan, proses TI yang akan dianalisis diurutkan seperti pada Tabel 10 .

Tabel 9. Pemetaan Tujuan TI dengan Proses TI pada PT. XYZ

\begin{tabular}{|c|c|}
\hline $\begin{array}{l}\text { Tujuan } \\
\text { TI }\end{array}$ & Proses TI \\
\hline 1 & $\begin{array}{l}\text { PO1, PO2, PO4, PO10, AI1, AI6, AI7, } \\
\text { DS1, DS3, ME1 }\end{array}$ \\
\hline 2 & PO1, PO4, PO10, ME1, ME4 \\
\hline 3 & $\begin{array}{l}\text { PO8, AI4, DS1, DS2, DS7, DS8, DS10, } \\
\text { DS13 }\end{array}$ \\
\hline 4 & PO2, DS11 \\
\hline 5 & $\mathrm{PO} 2, \mathrm{PO} 4, \mathrm{PO} 7, \mathrm{AI} 3$ \\
\hline 6 & $\mathrm{AI} 1, \mathrm{AI} 2, \mathrm{AI} 6$ \\
\hline 7 & $\mathrm{PO} 3, \mathrm{AI} 2, \mathrm{AI} 5$ \\
\hline 8 & $\mathrm{AI} 3, \mathrm{AI} 5$ \\
\hline 10 & DS2 \\
\hline 11 & $\mathrm{PO} 2, \mathrm{AI} 4, \mathrm{AI} 7$ \\
\hline 12 & PO5, PO6, DS1, DS2, DS6, ME1, ME4 \\
\hline 13 & PO6, AI4, AI7, DS7, DS8 \\
\hline 16 & PO8, AI4, AI6, AI7, DS10 \\
\hline 18 & PO9 \\
\hline 20 & PO6, AI7, DS5 \\
\hline 22 & PO6, AI6, DS4, SD12 \\
\hline 23 & DS3, DS4, DS8, DS13 \\
\hline 24 & PO5, DS6 \\
\hline 26 & AI6, DS5 \\
\hline 28 & PO5, DS6. ME1, ME4 \\
\hline
\end{tabular}

Tabel 10. Proses TI yang harus Dianalisis pada PT. XYZ

\begin{tabular}{|c|c|}
\hline Proses TI & Nama Proses TI \\
\hline PO1 & Define a strategic IT plan \\
\hline $\mathrm{PO} 2$ & Define the information architecture \\
\hline PO3 & Determine technological direction \\
\hline PO4 & $\begin{array}{l}\text { Define the IT processes, organisation and } \\
\text { relationship }\end{array}$ \\
\hline PO5 & Manage the IT investment \\
\hline PO6 & $\begin{array}{l}\text { Communicate management aims and } \\
\text { direction }\end{array}$ \\
\hline PO7 & Manage IT human resources \\
\hline PO8 & Manage quality \\
\hline PO9 & Assess and manage IT risk \\
\hline PO10 & Manage projects \\
\hline AI1 & Identify automated solutions \\
\hline AI2 & Acquire and maintain application software \\
\hline $\mathrm{AI} 3$ & $\begin{array}{l}\text { Acquire and maintain technology } \\
\text { infrastructure }\end{array}$ \\
\hline AI4 & Enable operation and use \\
\hline AI5 & Procure IT resources \\
\hline AI6 & Manage change \\
\hline AI7 & Install and accredit solutions and changes \\
\hline DS1 & Define and manage service levels \\
\hline DS2 & Manage third party services \\
\hline DS3 & Manage performance and capacity \\
\hline DS4 & Ensure continuous service \\
\hline DS5 & Ensure system security \\
\hline DS6 & Identify and allocate costs \\
\hline DS7 & Educate and train users \\
\hline DS8 & Manage service desk and incident \\
\hline DS10 & Manage problem \\
\hline DS11 & Manage data \\
\hline DS12 & Manage the physical environment \\
\hline DS13 & Manage operations \\
\hline ME1 & Monitor and evaluate IT performance \\
\hline ME4 & Provide IT governance \\
\hline
\end{tabular}

Semua proses yang tertera pada Tabel 10 adalah hasil akhir dari penelitian ini, yang selanjutnya dapat digunakan untuk dianalisis untuk mengetahui tingkat kematangan (maturity level) SI/ TI pada PT. XYZ.

\section{Kesimpulan}

\subsection{Simpulan}

Berdasarkan hasil penelitian yang telah dilakukan, maka dapat ditarik kesimpulan sebagai berikut:

1. Analisis yang telah dilakukan menggunakan SAM menunjukkan bahwa strategi bisnis dan strategi TI 
pada PT. XYZ telah selaras dan berada pada perspektif transformasi teknologi (technology transformation).

2. Pemetaan yang telah dilakukan menggunakan kerangka kerja COBIT 4.1 menghasilkan bahwa proses TI yang harus diaudit untuk tahap selanjutnya adalah sebanyak 31 proses dari total 34 proses yang terdapat pada COBIT 4.1, yaitu PO1, PO2, PO3, PO4, PO5, PO6, PO7, PO8, PO9, PO10, AI1, AI2, AI3, AI4, AI5, AI6, AI7, DS1, DS2, DS3, DS4, DS5, DS6, DS7, DS8, DS10, DS11, DS12, DS13, ME1, dan ME4.

\subsection{Saran}

Hasil dari penelitian ini yang berupa 31 proses TI dapat dilanjutkan untuk bahan audit pada PT. XYZ sehingga didapatkan nilai kematangannya. Diharapkan ke depannya akan ada penelitian lain yang sejenis dengan tempat studi kasus yang berbeda dan/ atau dengan pemakaian tools analisis yang berbeda. Peneliti selanjutnya diharapkan dapat melakukan pendekatan yang lebih mendalam dan komprehensif.

\section{Daftar Rujukan}

[1] Loudon, K.C., 2012. Management Information System: Managing The Digital Firm. Twelfth Edition. New Jersey: Prentice Hall Inc.

[2] Hamzah, A., 2007. Penyelarasan Strategi Bisnis dan Strategi Sistem/ Teknologi Informasi Untuk Peningkatan Kinerja Organisasi. In: Jurusan Teknik Informatika Fakultas Teknik Industri Universitas Islam Indonesia, Seminar Nasional Aplikasi
Teknologi Informasi 2007 (SNATI 2007). Yogyakarta, 16 Juni 2007, SNATI: Yogyakarta.

[3] The Institute of Internal Auditors, 2012. Global Technology Audit Guide (GTAG®) 17 Auditing IT Governance. Altamonte Springs, Fla., USA: IIA.

[4] IT Governance Institute., 2007. COBIT 4.1 Framework, Control Objective, Management Guidelines, Maturity Models. Rolling Meadows, IL 60008 USA: ITGI.

[5] Henderson, J. C. \& Venkartraman, N. 1999. Strategic Alignment: Leveraging Information Technology for Transforming Organizations. IBM System Journal, Vol. 38, pp. 472-484.

[6] Adityawarman, 2012. Pengukuran Tingkat Kematangan Penyelarasan Strategi Teknologi Informasi Terhadap Strategi Bisnis Analisis Menggunakan Framework Cobit 4.1 (Studi Kasus Pt. Bri, Tbk). Jurnal Akuntansi \& Auditing, Vol. 8 (No. 2), pp 166-177.

[7] Jelvino, Johanes, 2017. Audit Sistem Informasi Absensi pada PT. Bank Central Asia Tbk menggunakan COBIT 4.1. Jurnal Teknik Informatika dan Sistem Informasi, Vol 3 (No. 2), pp 259-268.

[8] Wibowo. "Penilaian Tingkat Kematangan Keselarasan Strategi Teknologi Informasi Terhadap Strategi Organisasi Studi Kasus : Sekretariat Negara”. Karya Akhir, Fakultas Ilmu Komputer MTIUI, 2010.

[9] Fitroh. 2012. Penilaian Tingkat Kematangan Tata Kelola TI pada Sistem Informasi Manajemen Akademik. In: Jurusan Teknik Informatika Fakultas Teknik Industri Universitas Islam Indonesia, Seminar Nasional Aplikasi Teknologi Informasi 2012 (SNATI 2012), Yogyakarta, 15-16 Juni 2012, SNATI: Yogyakarta.

[10]Marcel, Yuwono, B., 2013. Penilaian Tingkat Kematangan Keselarasan Strategi Bisnis dan TI (Studi Kasus Universitas XYZ). In: Jurusan Sistem Informasi, Institut Teknologi Sepuluh Nopember (ITS), Seminar Nasional Sistem Informasi Indonesia. Bali, 2-4 Desember 2013, Sesindo 2013: Surabaya/

[11]Dicky, 2014. Pengukuran Keselarasan Strategi Teknologi Informasi dan Strategi Bisnis dengan Model Luftman (Studi Kasus : AMIK XYZ). In: STMIK Potensi Utama, Seminar Nasional Informatika 2014 Audit Sistem dan Teknologi Informasi. Medan, 13 September 2014, SNIF 2014: Medan 